(c) American Dairy Science Association, 2005.

\title{
Manipulating the Dietary Cation-Anion Difference via Drenching to Early-Lactation Dairy Cows Grazing Pasture
}

\author{
J. R. Roche, S. Petch, and J. K. Kay \\ Dexcel Ltd., Hamilton, New Zealand
}

\section{ABSTRACT}

Diets offered to grazing dairy cows can vary considerably in their dietary cation-anion difference (DCAD) and are often well in excess of what has been considered optimal. The effects of a range of DCAD on the health and production of pasture-based dairy cows in early lactation was examined in a randomized block design. Four groups of 8 cows were offered a generous allowance of pasture $(45 \pm 6 \mathrm{~kg} / \mathrm{d}$ of dry matter (DM) per cow) for $35 \mathrm{~d}$ and achieved mean pasture intakes of approximately $17 \mathrm{~kg} / \mathrm{d}$ of DM per cow. Cows were drenched twice daily with varying combinations of mineral compounds to alter the DCAD. Dietary cation-anion difference ranged from +23 to $+88 \mathrm{mEq} / 100 \mathrm{~g}$ of DM. A linear increase in blood $\mathrm{pH}$ and $\mathrm{HCO}_{3}{ }^{-}$concentration and blood base excess, and a curvilinear increase in the $\mathrm{pH}$ of urine with increasing DCAD indicated a nonrespiratory effect of DCAD on metabolic acid-base balance. Plasma concentrations of $\mathrm{Mg}, \mathrm{K}$, and $\mathrm{Cl}$ declined as DCAD increased, whereas Na concentration increased. Urinary excretion of $\mathrm{Ca}$ decreased linearly as DCAD increased, although the data suggest that the decline may be curvilinear. These results in conjunction with the increased concentrations of ionized Ca suggest that intestinal absorption of $\mathrm{Ca}$ or bone resorption, or both, increased as DCAD declined. Dry matter intake, as measured using indigestible markers, was not significantly affected by DCAD. However, the linear increase in the yield of linolenic acid, vaccenic acid, and cis9, trans-11 conjugated linoleic acid in milk, as DCAD increased is consistent with a positive effect of DCAD on DM intake. Increasing DCAD did not significantly affect milk yield or milk protein, but the concentration and yield of milk fat linearly increased with increasing $\mathrm{DCAD}$. The increased milk fat yield was predominantly a result of increased de novo synthesis in the mammary epithelial cells, although an increase in the yield of preformed fatty acids also occurred. Milk production

Received April 30, 2004.

Accepted September 24, 2004.

Corresponding author: John Roche; e-mail: john.roche@ dexcel.co.nz. results suggest that DCAD for optimal production on pasture diets may be higher than the $+20 \mathrm{mEq} / 100 \mathrm{~g}$ of DM previously identified for total mixed rations. (Key words: lactating cow, dietary cation-anion difference, pasture, milk fatty acids)

Abbreviation key: DCAD = dietary cation-anion difference, CLA = cis-9, trans-11 conjugated linoleic acid, Creat $=$ creatinine, ICP-ES = inductively coupled plasma emission spectroscopy, $\mathbf{S F C}_{\mathbf{1 0}}=$ solid fat content at $10^{\circ} \mathrm{C},[\mathbf{S I D}]=$ strong ion difference, $\left[\mathbf{S I D}_{\mathbf{B}}\right]=$ serum [SID], SSID $\left._{\mathbf{U}}\right]=$ urine $[\mathrm{SID}], \mathbf{V A}=$ vaccenic acid.

\section{INTRODUCTION}

Research results have indicated that there is an optimum dietary cation-anion difference (DCAD) for maximum milk production. Tucker et al. (1988) reported that milk yield was $9 \%$ higher when a diet with a DCAD $(\mathrm{Na}+\mathrm{K}-\mathrm{Cl})$ of $+20 \mathrm{mEq} / 100 \mathrm{~g}$ of DM was fed compared with a DCAD of $-20 \mathrm{mEq} / 100 \mathrm{~g}$ of DM. Additionally, West et al. $(1991,1992)$ reported increases in milk yield and DMI when DCAD increased from -8 to $+32.4 \mathrm{mEq} /$ $100 \mathrm{~g}$ of $\mathrm{DM}$ and from +12 to $+46 \mathrm{mEq} / 100 \mathrm{~g}$ of $\mathrm{DM}$, respectively. These results, obtained under hot conditions, support the earlier work of Escobosa et al. (1984), who observed a reduction in milk production when cows were supplemented with anions $\left(2.28 \% \mathrm{CaCl}_{2}\right)$, and Schneider et al. (1986), who reported greater production in heat-stressed cows when dietary $\mathrm{K}$ levels exceeded levels recommended by NRC (1989).

Sanchez et al. (1994) estimated that milk yield and DMI were optimized at a DCAD of approximately +35 to $+40 \mathrm{mEq} / 100 \mathrm{~g}$ of $\mathrm{DM}$ using the DCAD equation $\mathrm{Na}$ $+\mathrm{K}-\mathrm{Cl}$. If $\mathrm{S}$ had been included in the equation to calculate DCAD $(\mathrm{Na}+\mathrm{K}-\mathrm{Cl}-\mathrm{S})$, pasture concentrations of S (Roche et al., 2000) would suggest an optimum DCAD of +15 to $+20 \mathrm{mEq} / 100 \mathrm{~g}$ of $\mathrm{DM}$ for cows fed pasture. Roche et al. (2003a) also reported a linear decline in DMI and BW gain in pasture-based dairy cows as DCAD increased above $+21 \mathrm{mEq} / 100 \mathrm{~g}$ of DM. However, natural variation in pasture DCAD between +15 and $+76 \mathrm{mEq} / 100 \mathrm{~g}$ of DM had no apparent effect on animal health or production (Roche et al., 2000). Morton and Roach (2002) also reported reduced DMI in cows 
grazing high $\mathrm{K}$ pastures in New Zealand. However, Chiy and Phillips (2000) reported an increase in milk yield and fat production in high yielding cows grazing pastures containing elevated sodium.

Pasture diets have several differences that relate to DCAD compared with TMR diets. The DCAD consumed by pasture-based cows in temperate regions can vary from 0 to $+76 \mathrm{mEq} / 100 \mathrm{~g}$ of $\mathrm{DM}$ (Roche et al., 2000), and little is known about the effect of such variation on cow health and production. Manipulation of DCAD in pasture diets via fertilizer has resulted in inconsistent effects, with DCAD increasing and decreasing with the application of $\mathrm{K}$ fertilizer in 2 separate years (Roche et al., 2002). Roche et al. (2003a,b) suggested that the only way to consistently manipulate DCAD in grazing systems was through oral supplementation of mineral compounds twice daily at milking time. With the exception of Roche et al. (2003a), DCAD in excess of +25 $\mathrm{mEq} / 100 \mathrm{~g}$ of $\mathrm{DM}$ have not been studied in lactating dairy cows offered fresh pasture. In particular, the model presented by Sanchez et al. (1994) has not been tested with DCAD greater than $+50 \mathrm{mEq} / 100 \mathrm{~g}$. Furthermore, the detailed effects of DCAD on milk composition have not been previously reported.

In the experiment reported here we attempted to find the optimum DCAD for lactating cows grazing fresh pasture and determine the repercussions for milk production from deviating from this point.

\section{MATERIALS AND METHODS}

This experiment was conducted at No. 5 Dairy, Dexcel, Hamilton, New Zealand $\left(37^{\circ} 46^{\prime} \mathrm{S}, 175^{\circ} 18^{\prime} \mathrm{E}\right)$ and lasted 35 d during September and October 2002. All procedures were approved by the Ruakura Animal Ethics Committee, AgResearch, Hamilton, New Zealand.

\section{Experimental Design}

Thirty-two multiparous Holstein-Friesian cows (4 \pm $1.2 \mathrm{yr}$; mean age $\pm \mathrm{SD}$ ), selected to calve over a 16-d period (August 2, $2002 \pm 8.4 \mathrm{~d}$; mean calving date \pm $\mathrm{SD})$, were randomly allocated to 4 dietary treatments (8 cows per treatment). Cows were 48 DIM; mean BW $(476 \pm 45 \mathrm{~kg})$ and BCS $(2.1 \pm 0.2)$ did not differ between treatments.

\section{Grazing Management}

Cows were rotationally grazed as one herd, in a similar method to that described by Roche et al. (2002). Briefly, cows had access to 40 paddocks (defined grazing area) of 0.25 ha each, and the paddocks were grazed in a rotational order. As a result, cows had access to a fresh allocation of pasture twice daily and only returned to the same area when a minimum of 2 leaves had appeared on the majority ( $>66 \%$ ) of perennial ryegrass tillers. Cows were generously fed, being offered $45 \pm 2.6$ $\mathrm{kg} / \mathrm{d}$ of pasture DM, so that intake was not restricted.

The sward consisted of approximately $60 \%$ perennial ryegrass (Lolium perenne L.) leaf, 8.5\% perennial ryegrass (Lolium perenne L.) stem, $28 \%$ weeds and other grasses (Dactylus glomerata, Holcus lanatus, and some Poa species), $1 \%$ white clover (Trifolium repens), and $2.5 \%$ dead material on a DM basis. The nutritive characteristics and mineral concentrations of the pasture offered are presented in Table 1.

The paddocks used had 2 to 4 wk of pasture regrowth. Pregrazing pasture heights averaged $10 \pm 1.2 \mathrm{~cm}$, and pregrazing mass was $2870 \pm 302 \mathrm{~kg} / \mathrm{ha}$ (mean \pm SD) of DM. Postgrazing residual pasture height averaged 6.1 $\pm 1.0 \mathrm{~cm}$ and the pasture mass remaining after grazing averaged $1920 \pm 260 \mathrm{~kg} / \mathrm{ha}$ (mean $\pm \mathrm{SD}$ ) of DM.

\section{Dietary Cation-Anion Difference}

Dietary cation-anion difference is the difference, in milliequivalents, between certain cations and anions in the diet. It is calculated by subtracting the milliequivalents of $\mathrm{Cl}$ and $\mathrm{S}$ from the milliequivalents of $\mathrm{Na}$ and $\mathrm{K}$, in all feeds (Tucker et al., 1992):

$$
\mathrm{DCAD}=(\mathrm{Na}+\mathrm{K})-(\mathrm{Cl}+\mathrm{S})(\mathrm{mEq} / 100 \mathrm{~g} \text { of } \mathrm{DM})
$$

To create a range of $\mathrm{DCAD}$ treatments, the diet was supplemented with salts of $\mathrm{Na}, \mathrm{Cl}$, or $\mathrm{S}$, such that 4 treatments received a planned DCAD of $+20,+40,+60$, and $+80 \mathrm{mEq} / 100 \mathrm{~g}$ of DM. The preexperimental cationanion difference of pasture was $+53 \pm 4.9 \mathrm{mEq} / 100 \mathrm{~g}$ (mean \pm SD) of DM. Table 2 presents salts used and daily quantities administered. Calcium chloride $\left(\mathrm{CaCl}_{2} \cdot 2 \mathrm{H}_{2} \mathrm{O}\right)$ and magnesium chloride $\left(\mathrm{MgCl}_{2} \cdot 6 \mathrm{H}_{2} \mathrm{O}\right)$ were used to reduce the $\mathrm{DCAD}$, and $\mathrm{NaHCO}_{3}$ used to increase DCAD. Sodium bicarbonate was chosen to increase the DCAD as it is the most commonly supplemented cationic salt in pasture-based scenarios, and the research of West et al. (1992) showed that cation source ( $\mathrm{Na}$ or $\mathrm{K}$ ) was not important. Magnesium oxide and $\mathrm{CaCO}_{3}$ were used to balance the dietary $\mathrm{Mg}$ and Ca concentrations, respectively. Dietary Ca was $1.27 \pm$ $0.04 \% \mathrm{DM}$, and dietary $\mathrm{Mg}$ was $0.4 \pm 0.02 \% \mathrm{DM}$ (mean $\pm \mathrm{SD})$.

Cows received the appropriate salt mixture as a drench before milking at 0730 and $1530 \mathrm{~h}$. If DCAD is to be accurately manipulated in pasture-based systems it will be through supplementation of cows with appropriate salt mixtures once or twice daily, as the consistent and predictable manipulation of DCAD has been 
ROCHE ET AL.

Table 1. Weekly and mean $( \pm \mathrm{SD})$ nutrients, $\mathrm{NE}_{\mathrm{L}}$, macro-mineral, and trace mineral composition and dietary cation-anion difference (DCAD) of pasture offered to dairy cows in early lactation.

\begin{tabular}{|c|c|c|c|c|c|c|c|}
\hline & \multicolumn{5}{|c|}{ Week } & \multirow[b]{2}{*}{ Mean } & \multirow[b]{2}{*}{$\mathrm{SD}$} \\
\hline & 1 & 2 & 3 & 4 & 5 & & \\
\hline $\mathrm{CP}(\%$ of $\mathrm{DM})$ & 29.8 & 29.5 & 28.6 & 27.1 & 27.8 & 28.6 & 1.1 \\
\hline $\mathrm{NDF}(\%$ of DM) & 34.5 & 37.5 & 34.3 & 35.3 & 38.4 & 36.0 & 1.8 \\
\hline $\mathrm{ADF}(\%$ of $\mathrm{DM})$ & 17.7 & 18.7 & 16.8 & 18.3 & 19.6 & 18.2 & 1.1 \\
\hline Lipid (\% of DM) & 4.5 & 4.4 & 4.2 & 4.2 & 4.3 & 4.3 & 0.1 \\
\hline \multicolumn{8}{|l|}{ Nonstructural } \\
\hline $\mathrm{NE}_{\mathrm{L}}(\mathrm{Mcal} / \mathrm{kg}$ of $\mathrm{DM})$ & 1.94 & 1.94 & $\begin{array}{r}14.0 \\
1.97\end{array}$ & 1.97 & 1.85 & 1.93 & 0.1 \\
\hline \multicolumn{8}{|l|}{ Macro-minerals (\% of DM) } \\
\hline Ash & 11.1 & 10.8 & 10.5 & 10.8 & 10.6 & 10.8 & 0.2 \\
\hline $\mathrm{Na}$ & 0.31 & 0.30 & 0.35 & 0.27 & 0.28 & 0.30 & 0.03 \\
\hline $\mathrm{K}$ & 3.50 & 3.90 & 3.80 & 3.70 & 3.80 & 3.74 & 0.15 \\
\hline $\mathrm{Cl}$ & 1.10 & 1.00 & 1.10 & 1.10 & 1.20 & 1.10 & 0.07 \\
\hline $\mathrm{S}$ & 0.35 & 0.37 & 0.34 & 0.34 & 0.39 & 0.36 & 0.02 \\
\hline $\mathrm{Ca}$ & 0.48 & 0.47 & 0.52 & 0.47 & 0.49 & 0.49 & 0.02 \\
\hline $\mathrm{Mg}$ & 0.16 & 0.21 & 0.20 & 0.20 & 0.20 & 0.19 & 0.02 \\
\hline $\mathrm{P}$ & 0.39 & 0.39 & 0.31 & 0.32 & 0.33 & 0.35 & 0.04 \\
\hline DCAD $(\mathrm{mEq} / 100 \mathrm{~g}$ of $\mathrm{DM})$ & 50 & 62 & 60 & 54 & 51 & 55 & 5.2 \\
\hline \multicolumn{8}{|l|}{ Trace minerals $(\mathrm{mg} / \mathrm{kg})$} \\
\hline $\mathrm{Cu}$ & 7 & 5 & 5 & 3 & 5 & 5 & 1.4 \\
\hline Co & 0.17 & 0.07 & 0.04 & 0.04 & 0.05 & 0.07 & 0.06 \\
\hline $\mathrm{Se}$ & 0.12 & 0.08 & 0.12 & 0.12 & 0.11 & 0.11 & 0.02 \\
\hline I & 0.35 & 0.25 & 0.17 & 0.13 & 0.13 & 0.21 & 0.09 \\
\hline $\mathrm{Zn}$ & 38 & 31 & 32 & 36 & 31 & 34 & 3.2 \\
\hline $\mathrm{Fe}$ & 520 & 200 & 130 & 120 & 150 & 224 & 168.3 \\
\hline $\mathrm{Mn}$ & 93 & 61 & 48 & 47 & 45 & 59 & 20.1 \\
\hline Mo & 0.70 & 0.83 & 0.68 & 0.66 & 0.55 & 0.68 & 0.10 \\
\hline B & 4 & 3 & 5 & 5 & 3 & 4 & 1.0 \\
\hline
\end{tabular}

very difficult (Roche et al., 2002). Furthermore, the pasture-based system, where cows are generally a considerable distance from supplementation facilities, precludes a more frequent supplementation strategy. In support of this method, Roche (1999) showed increased $\mathrm{Ca}$ absorption and urinary $\mathrm{Ca}$ excretion and little or no diurnal variation in urine $\mathrm{pH}$ when anionic salts were supplemented twice daily to reduce the DCAD to $-20 \mathrm{mEq} / 100 \mathrm{~g}$ of $\mathrm{DM}$, thereby suggesting that twicedaily supplementation of anionic salts in pasture-based systems had similar effects to continuous supplementation in a TMR.

Table 2. Quantities (g) and equivalents (eq/d) of the different mineral compounds administered daily ${ }^{1}$ to dairy cows in early lactation grazing fresh pasture, to alter the dietary cation-anion difference (DCAD) and balance the diets for $\mathrm{Ca}$ and $\mathrm{Mg}$ concentration.

\begin{tabular}{lcccc}
\hline & \multicolumn{4}{c}{ Proposed DCAD $(\mathrm{mEq} / 100 \mathrm{~g}$ of DM) } \\
\cline { 2 - 5 } Mineral compound & 20 & 40 & 60 & 80 \\
\hline $\mathrm{NaHCO}_{3}$ & 0 & 0 & 100 & 360 \\
$\mathrm{CaCl}_{2} \cdot 2 \mathrm{H}_{2} 0$ & 270 & 110 & 0 & 0 \\
$\mathrm{MgCl}_{2} \cdot 6 \mathrm{H}_{2} \mathrm{O}$ & 160 & 70 & 0 & 0 \\
$\mathrm{MgO}$ & 30 & 40 & 60 & 60 \\
$\mathrm{CaCO}$ & 130 & 250 & 350 & 350 \\
DCAD added (eq/d) & -5.8 & -2.4 & +1.2 & +4.2 \\
\hline
\end{tabular}

${ }^{1}$ Salts were administered orally via drench in 2 equal doses at 0730 and $1530 \mathrm{~h}$.
As the DCAD of the diet was high, and the amounts of salts required to reduce or increase it to the predetermined levels were so great, the salts used were administered orally in solution. The solution was administered in $150-\mathrm{mL}$ aliquots, which successfully minimized the risk of aspirating the salt mixture.

\section{Pasture Measurements}

Pre- and postgrazing pasture yields were visually assessed as outlined by Roche et al. (2002). One experienced assessor was calibrated weekly through cutting a range of pasture yields, representative of pre- and postgrazing yields (O'Donovan, 2000). Pasture height was measured pre- and postgrazing using a Rising Plate Meter installed with an electronic counter (Farmworks, Palmerston North, New Zealand).

Representative samples of pasture were collected by 'plucking' pasture to grazing height from paddocks due to be grazed. Samples were bulked weekly, and duplicate samples were dried at $100^{\circ} \mathrm{C}$ for $\mathrm{DM}$ analysis, or at $60^{\circ} \mathrm{C}$ for analysis of nutrient composition. All samples dried at $60^{\circ} \mathrm{C}$ were dried for $48 \mathrm{~h}$, ground to pass through a $1.0-\mathrm{mm}$ sieve (Christy Laboratory Mill, Suffolk, UK) and analyzed for CP, NDF, ADF, nonstructural carbohydrates, fat, ash, and metabolizable energy by near infrared spectroscopy. Bulked pasture samples 
were analyzed weekly for minerals by inductively coupled plasma emission spectroscopy (ICP-ES). Pasture chlorine was measured using potentiometric titration following $2 \%$ nitric acid extraction. Net energy for lactation was calculated from metabolizable energy (ME) by:

$$
\mathrm{NE}_{\mathrm{L}}=\mathrm{ME} \times 0.65 \text { (Holmes and Wilson, 1987). }
$$

\section{Animal Measurements}

Dry matter intake. Individual animal intake estimates were obtained at pasture using the n-alkane technique (Mayes et al., 1986), as modified by Dillon and Stakelum (1989) and outlined by Kennedy et al. (2003). Briefly, each cow was dosed twice daily (at milking) for a 10-d period with a pellet containing $356 \mathrm{mg}$ of n-dotriacontane (C32) (i.e., $712 \mathrm{mg}$ of C32 daily for each cow). Fecal grab samples were collected twice daily from each cow (after milking) during the last $5 \mathrm{~d}$ of the 10-d period. The fecal samples from each cow for the 5 -d period were bulked and stored at $-17^{\circ} \mathrm{C}$ awaiting alkane analysis. During the same 5-d period, pasture samples were "plucked" to grazing height, following close observation of the grazing animal, to represent pasture grazed. The n-alkane contents (C25-C36) of the pasture and feces were analyzed by gas chromatography using a modification of the method of Mayes et al. (1986), which used direct saponification (Dillon, 1993).

The ratio of herbage C33 (tritriacontane) to dosed C32 (n-dotriacontane) was used to estimate intake. Estimates of daily herbage intake were calculated as follows:

$$
\frac{F_{i} / F_{j} \times D_{j}}{P_{i}-\left(F_{i} / F_{j} \times P_{j}\right)}
$$

where $F_{i}$ and $P_{i}$ are the concentrations ( $\mathrm{mg} / \mathrm{kg}$ of $\left.\mathrm{DM}\right)$ of the natural odd-chain n-alkanes (C33) in feces and pasture, respectively, $F_{j}$ and $P_{j}$ are the concentrations $(\mathrm{mg} / \mathrm{kg}$ of DM) of the dosed even-chain n-alkane (C32) in feces and pasture, respectively, and $D_{j}$ is the dose rate $(\mathrm{mg} / \mathrm{d})$ of the even-chain $\mathrm{n}$-alkane (C32).

Milk and $\boldsymbol{B W}$. Individual milk yields were recorded daily (Trutest milk meter system, Palmerston North, New Zealand). Fat, CP, true protein, casein, and lactose concentrations of milk were determined by Milkoscan (Foss Electric, Hillerød, Denmark) on individual p.m. and a.m. aliquot samples collected on $2 \mathrm{~d}$ each wk. Milk component data were verified by reference techniques for a subset of milk samples [milk fat: Röse-Gottlieb (IDF, 1987); crude protein, true protein, and casein: macro-Kjeldahl techniques (Barbano et al., 1991)]. Somatic cell count was measured using an automated cell counter (Fossomatic 5000; Foss Electric). Milk minerals were determined using ICP-ES. Cows were weighed weekly before the a.m. milking, and BCS was assessed weekly by one experienced assessor.

Milk fat. During wk 5 of the experiment, milk fat was extracted from the fresh milk samples using the Röse-Gottlieb fat extraction procedure (IDF, 1987) and stored at $-20^{\circ} \mathrm{C}$ until analysis for solid fat content at $10^{\circ} \mathrm{C}\left(\mathbf{S F C}_{\mathbf{1 0}}\right)$, and fatty acid composition.

Solid fat content at $10^{\circ} \mathrm{C}$ of milk samples was measured by pulsed nuclear magnetic resonance as described by MacGibbon and McLennan (1987). All samples were melted and recrystallized under identical conditions, and thus, changes in $\mathrm{SFC}_{10}$ reflect changes in composition. Results refer to proportion of fat that is solid at $10^{\circ} \mathrm{C}$

Fatty acid methyl esters were quantified by gas chromatography after methylation using sodium methoxide as described by MacGibbon (1988). Gas chromatographic analyses of fatty acid methyl esters were performed on a GC-17A equipped with a flame ionization detector, an auto-sampler, and auto-injector (Shimadzu Corporation, Kyoto, Japan). A 120-m BPX-70 column $(120 \mathrm{~m} \times 0.25 \mathrm{~mm}$ i.d. and $0.25 \mu \mathrm{m}$ film thickness; SGE, Australia) was used and $0.2 \mu \mathrm{L}$ of solvent solution was injected using on-column injection technique combined with programmed temperature volatilization. The initial temperature was set at $80^{\circ} \mathrm{C}$ for $0.1 \mathrm{~min}$ and then increased to $230^{\circ} \mathrm{C}$ at a rate of $25^{\circ} \mathrm{C} / \mathrm{min}$. The initial oven temperature was $80^{\circ} \mathrm{C}$, increased to $190^{\circ} \mathrm{C}$ at a rate of $2^{\circ} \mathrm{C} / \mathrm{min}$, and held for $25 \mathrm{~min}$. Injector and detector temperature was set at $250^{\circ} \mathrm{C}$.

Standards for conjugated linoleic acid (CLA) and other fatty acids were obtained from Matreya Inc. (Pleasant Gap, PA), and CLA isomer mixes from Sigma Chemical Co. (St. Louis, MO) and NuCheck Prep (Elysian, MN). In addition, a butter reference standard (CRM 164; Commission of the European Communities, Community Bureau of Reference, Brussels, Belgium) was used as a qualitative reference for individual fatty acids, and GLC 87 and 74X (NuCheck Prep) were used as quantitative methyl ester references.

The total color ( $\beta$-carotene equivalents) of milk was measured by the absorbance of milk fat after the samples' fat had been extracted in petroleum ether (Norris et al., 1971).

Milk protein. Concentrations of $\alpha-, \beta-, \kappa_{-}$, and $\gamma-$ casein, $\alpha$-lactalbumin ( $\alpha$-LA), and $\beta$-lactoglobulin $(\beta$ LG) were determined by SDS-PAGE according to the method of Manderson et al. (1998) and with modifications described by Mackle et al. (1999). Bovine serum albumin and total IgG were determined using a commercially available radial immunodiffusion kit according to the manufacturer's instructions (The Bind- 
ing Site Ltd, Birmingham, UK). Lactoferrin concentrations in milk were measured using a bovine lactoferrin ELISA quantification kit (Bethyl Laboratories, Inc., Montgomery, TX). Milk urea (urease method) analyses were completed on skim milk samples on the Hitachi 717 analyzer.

Blood. Two evacuated blood tubes, one containing a sodium heparin pellet (100 IU of sodium heparin/mL of blood) to prevent coagulation and one with no additive were collected by jugular venipuncture of each cow twice weekly. Blood from the heparinized blood tube was used to determine blood $\mathrm{pH}$, total $\mathrm{CO}_{2}$, partial pressure of $\mathrm{CO}_{2}$ and $\mathrm{O}_{2}$ (in $\mathrm{kPa}$ ), $\mathrm{HCO}_{3}{ }^{-}$, base excess, solubility of $\mathrm{O}_{2}$, and ionized $\mathrm{Ca}$ within $30 \mathrm{~min}$ of sampling, using a blood analyzer (i-stat handheld analyzer, ISTAT Corp., Princeton, NJ). Serum from the plain tube was harvested $\left(1120 \times \mathrm{g}, 10 \mathrm{~min}, 4^{\circ} \mathrm{C}\right)$ and analyzed for mineral, BHBA, and urea concentration. Serum trace minerals, other than Se, were determined by ICP-ES following nitric acid-assisted microwave digestion. Serum Se was determined using hydride generation following acid digestion. $\beta$-Hydroxybutyrate (BHBA dehydrogenase assay), glucose (hexakinase method), urea (urease method), calcium (o-Cresolphthalein complexone), magnesium (xylidyl blue reaction), and phosphorus (molybdate reaction) analyses were performed on a Hitachi 717 analyzer (Roche, Basel, Switzerland) at $30^{\circ} \mathrm{C}$. Sodium, $\mathrm{K}$, and $\mathrm{Cl}$ were analyzed using ionselective electrodes on a Medica Easylyte stand-alone analyzer (Diamond Diagnostics, Holliston, MA). The inter- and intraassay coefficient of variation was $<2 \%$ for all assays.

Urine. Cows were manually stimulated to urinate 3 times/wk at $0700 \mathrm{~h}$, and a sample of midstream urine was collected in a $30-\mathrm{mL}$ container. Within $30 \mathrm{~min}$ of collection, $\mathrm{pH}$ was measured and a $10-\mathrm{mL}$ aliquot was stored at $-17^{\circ} \mathrm{C}$ awaiting analysis. Urine Ca (o-Cresolphthalein complexone), $\mathrm{Mg}$ (xylidyl blue), $\mathrm{Na}$ (ionselective electrode), $\mathrm{K}$ (ion-selective electrode), $\mathrm{Cl}$ (mercuric thiocyanate; Sigma), P (ammonium molybdate), and creatinine (Jaffe) were determined on the Hitachi 717 analyzer (Roche) at $30^{\circ} \mathrm{C}$ by Alpha Scientific Ltd. (Hamilton, New Zealand) using Roche/Hitachi reagents. The intra- and interassay coefficient of variation was $<2$ and $<5 \%$, respectively, for all assays.

Liver. Biopsies were obtained before treatment initiation and again on the final day of the experiment $(\mathrm{d}$ 35). Liver tissue samples were analyzed for $\mathrm{Zn}$ and $\mathrm{Cu}$ by flame atomic absorption and Se by hydride generation. All analyses were preceded by acid digestion. Vitamin $B_{12}$ concentration of liver tissue was determined using an isotope dilution method (Green et al., 1974).

\section{Calculations}

Urinary minerals ( $\mathrm{Ca}, \mathrm{Mg}, \mathrm{Na}, \mathrm{Cl}$, and $\mathrm{S}$ ) were expressed as ratios to creatinine (Creat) concentration to overcome variations in urine volume among animals (Roche et al., 2002).

The DCAD was calculated using the equation of Tucker et al. (1992) and included the quantities of the salts administered and the measured mineral concentrations and DMI of all feeds.

$$
\mathrm{DCAD}=(\mathrm{Na}+\mathrm{K})-(\mathrm{Cl}+\mathrm{S})(\mathrm{mEq} / 100 \mathrm{~g} \text { of } \mathrm{DM})
$$

The strong ion difference [SID] is the difference, in milliequivalents, between certain cations and anions in body fluids (Stewart, 1983) and is calculated by subtracting the $\mathrm{mEq}$ of $\mathrm{Cl}$ and $\mathrm{S}$ from the $\mathrm{mEq}$ of $\mathrm{Na}$ and $\mathrm{K}$, in either serum or urine ([SID $\mathbf{B}]$ and $\left[\mathbf{S I D}_{\mathbf{U}}\right]$, respectively).

Milk fatty acids are expressed as the amount of each individual fatty acid per total fatty acids present. This involved transforming data from the GLC analysis (fatty acid methyl esters) to a fatty acid basis. $\Delta^{9}$-Desaturase indices, which act as proxies for $\Delta^{9}$-desaturase activity, were calculated for 5 pairs of fatty acids that represent product and substrates for $\Delta^{9}$-desaturase (cis-9 10:1/10:0, cis-9 14:1/14:0, cis-9 16:1/16:0, cis-9 18:1/18:0, and cis-9, trans-11 18:2/trans-11 18:1). For example, the $\Delta^{9}$-desaturase index for cis-9 14:1 was calculated as follows:

$$
\text { [cis-9 14:1] / [cis-9 14:1 + 14:0] }
$$

An overall $\Delta^{9}$-desaturase index was calculated using all 5 fatty acid pairs dependent on $\Delta^{9}$-desaturase for production. The formula used was:

$$
\begin{aligned}
& \quad([c i s-910: 1]+[\text { cis-9 14:1] }+[\text { cis-9 16:1] } \\
& +[\text { cis-9 18:1]+[cis-9, trans } 11 \text { CLA }]) \\
& +([\text { cis-9 10:1 + 10:0]+[cis-9 14:1 + 14:0] } \\
& +[\text { cis-9 16:1 + 16:0]+[cis-9 18:1 + 18:0] } \\
& +[\text { cis-9, trans-11 CLA + trans-11 18:1]) }
\end{aligned}
$$

\section{Statistical Analysis}

For each cow, animal measurements were averaged over a 21-d period beginning $14 \mathrm{~d}$ after the onset of treatment, as approved by Everitt (1995). Somatic cell count data were $\log _{10}$ transformed to stabilize the variance before statistical analysis (SCS). Data were analyzed using REML, with cows as a random effect and linear and quadratic effects of DCAD dose as fixed effects. All data were analyzed using the statistical procedures in Genstat 5.4.1 (Genstat V, 1997). Pretreatment 
Table 3. Mean ( \pm SD) dietary cation-anion difference (DCAD) and mineral concentrations (\% of DM) consumed ${ }^{1}$ by early lactation dairy cows offered fresh pasture and orally supplemented with mineral compounds containing either $\mathrm{Na}, \mathrm{Cl}, \mathrm{Ca}$, or $\mathrm{Mg}$, or a mixture of these minerals.

\begin{tabular}{llccc}
\hline & \multicolumn{4}{c}{ Proposed DCAD $(\mathrm{mEq} / 100 \mathrm{~g}$ of DM $)$} \\
\cline { 2 - 4 } Mineral & 20 & 40 & 60 & 80 \\
\hline $\mathrm{Na}$ & $0.30 \pm 0.03$ & $0.32 \pm 0.03$ & $0.51 \pm 0.04$ & $0.96 \pm 0.03$ \\
$\mathrm{~K}$ & $3.74 \pm 0.15$ & $3.74 \pm 0.15$ & $3.74 \pm 0.15$ & $3.74 \pm 0.15$ \\
$\mathrm{Cl}$ & $2.27 \pm 0.07$ & $1.64 \pm 0.07$ & $1.24 \pm 0.08$ & $1.20 \pm 0.08$ \\
$\mathrm{~S}$ & $0.36 \pm 0.02$ & $0.36 \pm 0.02$ & $0.36 \pm 0.02$ & $0.36 \pm 0.02$ \\
$\mathrm{Ca}$ & $1.23 \pm 0.02$ & $1.25 \pm 0.02$ & $1.32 \pm 0.02$ & $1.30 \pm 0.02$ \\
$\mathrm{Mg}$ & $0.42 \pm 0.02$ & $0.39 \pm 0.02$ & $0.43 \pm 0.02$ & $0.42 \pm 0.02$ \\
$\mathrm{P}$ & $0.35 \pm 0.04$ & $0.35 \pm 0.04$ & $0.35 \pm 0.04$ & $0.35 \pm 0.04$ \\
Actual DCAD & $23 \pm 5.2$ & $45 \pm 5.4$ & $70 \pm 5.8$ & $88 \pm 5.7$ \\
\hline
\end{tabular}

${ }^{1}$ Minerals consumed in fresh pasture plus the amount contained in orally administered salts.

measurements were used as a covariate where significant. A probability of $<0.05$ was used to determine statistical significance unless otherwise noted.

\section{RESULTS}

The measured DCAD $[(\mathrm{Na}+\mathrm{K})-(\mathrm{Cl}+\mathrm{S})]$ consumed daily by the cows on each treatment were $+23( \pm 5.2)$, $+45( \pm 5.4),+70( \pm 5.8)$, and $+88( \pm 5.7) \mathrm{mEq} / 100 \mathrm{~g}$ of $\mathrm{DM}$ (mean $\pm \mathrm{SD}$; Table 3).

Blood $\mathrm{pH}$, total $\mathrm{CO}_{2}$, partial pressure of $\mathrm{CO}_{2}$, $\mathrm{HCO}_{3}{ }^{-}$, and base excess concentration increased linearly with increasing DCAD (Table 4). Neither partial pressure of $\mathrm{O}_{2}$ or solubility of $\mathrm{O}_{2}$ was affected by DCAD. The concentration of urea in blood increased $(P<0.001)$ linearly as DCAD increased, but the concentrations of glucose and BHBA in blood were not affected by DCAD.

Plasma Ca concentration was not affected by DCAD, but the concentration of ionized $\mathrm{Ca}$ and the proportion of $\mathrm{Ca}$ that was ionized declined $(P<0.01)$ as DCAD increased. Similarly, the concentration of $\mathrm{Mg}$ in blood decreased $(P<0.05)$ as DCAD increased. Blood Na concentration increased $(P<0.05)$ curvilinearly, and the concentration of $\mathrm{K}$ and $\mathrm{Cl}$ declined linearly $(P<0.001)$ as DCAD increased (Table 4). The concentration of $\mathrm{Fe}$ in blood increased $(P<0.05)$ with increasing DCAD but concentrations of $\mathrm{Se}, \mathrm{Zn}, \mathrm{Cu}, \mathrm{I}$, and $\mathrm{Co}$ in blood were not affected (data not shown). Table 4 also shows the effect of DCAD on the liver concentrations of $\mathrm{Zn}, \mathrm{Cu}$, $\mathrm{Se}$, and vitamin $\mathrm{B}_{12}$. Vitamin $\mathrm{B}_{12}$ concentration in liver declined $(P<0.01)$ with increasing DCAD, but the other parameters were unaffected.

Urine $\mathrm{pH}$ and $\left[\mathrm{SID}_{\mathrm{U}}\right]$ increased $(P<0.001)$ linearly as DCAD increased (Table 5), although the curvilinear response in $\mathrm{pH}$ was also significant $(P<0.05)$. Ca/Creat ratio declined linearly with increasing $\mathrm{DCAD}$, although the data suggest that the decline may be curvilinear $(P$ $<0.1) . \mathrm{Na} / \mathrm{Creat}$ and $\mathrm{Cl} /$ Creat ratios increased $(P<$ $0.001)$ and decreased $(P<0.001)$ linearly with increas- ing $\mathrm{DCAD}$, respectively, although like $\mathrm{Ca} / \mathrm{Creat}$, the data suggest that the decline may be curvilinear $(P<$ $0.1)$. The concentration of the other macrominerals $(\mathrm{Mg}$, $\mathrm{K}, \mathrm{S}$, and $\mathrm{P}$ ) in urine appeared unaffected by treatment (Table 5).

As DCAD increased, milk fat percentage and milk fat yield increased $(P<0.05$; Table 6$)$ linearly from 3.96 to $4.17 \%$ fat and from 1.0 to $1.1 \mathrm{~kg} / \mathrm{d}$ of fat per cow, respectively. Solid fat content at $10^{\circ} \mathrm{C}$ also increased $(P<0.001)$ linearly with increasing DCAD. Milk yield, and the yield and percentage of $\mathrm{CP}$, total protein, lactose, CN, minerals, and SCS in milk were not affected by DCAD. Across treatments, cows consumed pasture at $3.5 \pm 0.4 \%$ of $\mathrm{BW}$ on average (mean $\pm \mathrm{SD}$; Table 6 ); DMI (17.0 $\pm 2.6 \mathrm{~kg}$ of DM per cow; mean $\pm \mathrm{SD})$ was not significantly affected by changes in DCAD. Changes in BW and BCS were not affected by DCAD.

A change in DCAD resulted in distinct changes in milk fatty acid composition and in particular, the proportion of medium and long chain fatty acids (>16:0). Mean values from cows during wk 5 of the treatment period are presented in Table 7. Milk fat 16:0 concentration increased $(P<0.001)$ linearly with increasing DCAD, whereas the proportion of long chain fatty acids in milk (sum of 17:0 to 20:0) decreased $(P<0.05)$ linearly. In particular, the milk fat concentrations of margaric (C17:0), linoleic (cis-9, cis-12 18:2), oleic (cis-9 18:1), and stearic acids (18:0) declined $(P<0.05,0.05,0.01$, and 0.05 , respectively) linearly with increasing DCAD. The milk fat concentration of trans-12 18:1 declined ( $P$ $<0.01$ ) linearly as DCAD increased, and there was a trend toward increased trans-11 18:1 (vaccenic acid; VA; $P=0.14)$ as DCAD increased.

Table 7 also presents milk fatty acid yield and shows an increased $(P<0.05)$ yield of short $(4: 0$ to $15: 1)$ and medium chain (16:0 and 16:1) fatty acids with increasing DCAD, as well as an increased $(P<0.05)$ yield of VA, cis-9, trans-11 CLA, and linolenic acid (cis-9, cis12, cis-15 18:3). 
Table 4. Blood $\mathrm{pH}$, strong ion difference, total $\mathrm{CO}_{2}$, partial pressure of $\mathrm{CO}_{2}$, partial pressure of $\mathrm{O}_{2}$, solubility of $\mathrm{O}_{2}$, concentration of $\mathrm{HCO}_{3}{ }^{-}$, base excess, urea, glucose, BHBA, and minerals in blood and the concentration of $\mathrm{Zn}, \mathrm{Se}, \mathrm{Cu}$, and vitamin $\mathrm{B}_{12}$ in the liver of dairy cows in early lactation offered fresh pasture and orally supplemented with mineral compounds containing either $\mathrm{Na}, \mathrm{Cl}, \mathrm{Ca}$, or $\mathrm{Mg}$, or a mixture of these minerals, to alter the dietary cation-anion difference (DCAD).

\begin{tabular}{|c|c|c|c|c|c|c|c|c|}
\hline Variable & \multicolumn{4}{|c|}{$\mathrm{DCAD}(\mathrm{mEq} / 100 \mathrm{~g}$ of $\mathrm{DM})$} & SED & \multicolumn{3}{|c|}{$P$} \\
\hline Blood pH & 7.432 & 7.448 & 7.479 & 7.486 & 0.0071 & $<0.0001$ & $<0.0001$ & 0.52 \\
\hline Total $\mathrm{CO}_{2}, \mathrm{mmol} / \mathrm{L}$ & 32.68 & 33.94 & 36.20 & 39.41 & 1.189 & $<0.0001$ & $<0.0001$ & 0.23 \\
\hline Partial pressure of $\mathrm{CO}_{2}, \mathrm{kPa}$ & 46.93 & 46.99 & 46.92 & 50.23 & 1.278 & 0.04 & 0.03 & 0.07 \\
\hline Partial pressure of $\mathrm{O}_{2}, \mathrm{kPa}$ & 42.05 & 40.18 & 40.48 & 40.85 & 0.315 & 0.87 & 0.66 & 0.49 \\
\hline $\mathrm{HCO}_{3}^{-}, \mathrm{mmol} / \mathrm{L}$ & 31.27 & 32.49 & 34.66 & 38.03 & 1.154 & $<0.0001$ & $<0.0001$ & 0.18 \\
\hline Urea & 6.27 & 6.68 & 7.55 & 7.52 & 0.385 & 0.01 & 0.001 & 0.43 \\
\hline Glucose & 3.61 & 3.54 & 3.57 & 3.48 & 0.190 & 0.91 & 0.51 & 0.95 \\
\hline BHBA & 0.24 & 0.24 & 0.28 & 0.24 & 0.036 & 0.60 & 0.74 & 0.44 \\
\hline \multicolumn{9}{|l|}{ Minerals } \\
\hline Total Ca & 2.59 & 2.55 & 2.48 & 2.54 & 0.082 & 0.63 & 0.37 & 0.42 \\
\hline Ionized $\mathrm{Ca}$ & 1.28 & 1.23 & 1.24 & 1.19 & 0.024 & $<0.01$ & $<0.01$ & 0.89 \\
\hline Ionized $\mathrm{Ca} /$ total $\mathrm{Ca}$ & 49.6 & 48.3 & 47.4 & 47.2 & 0.60 & $<0.01$ & $<0.01$ & 0.25 \\
\hline $\mathrm{S}$ & 31.7 & 33.0 & 32.1 & 32.0 & 0.85 & 0.41 & 0.95 & 0.19 \\
\hline $\mathrm{P}$ & 1.17 & 1.30 & 1.22 & 1.17 & 0.138 & 0.76 & 0.78 & 0.34 \\
\hline $\mathrm{Se}$ & 1105 & 1237 & 1089 & 936 & 155.2 & 0.29 & 0.17 & 0.18 \\
\hline \multicolumn{9}{|l|}{ Liver } \\
\hline $\mathrm{Zn}, \mathrm{mg} / \mathrm{kg}$ & 402 & 446 & 387 & 428 & 42.2 & 0.56 & 0.76 & 0.40 \\
\hline $\mathrm{Se}, \mathrm{mg} / \mathrm{kg}$ & 3269 & 3313 & 3224 & 3242 & 374.6 & 0.99 & 0.95 & 0.91 \\
\hline $\mathrm{Cu}, \mathrm{mg} / \mathrm{kg}$ & 700 & 636 & 718 & 714 & 138.0 & 0.91 & 0.83 & 0.54 \\
\hline Vitamin $\mathrm{B}_{12}, \mathrm{mg} / \mathrm{kg}$ & 485 & 468 & 403 & 357 & 74.5 & 0.17 & $<0.01$ & 0.63 \\
\hline
\end{tabular}

${ }^{1}\left[\mathrm{SID}_{\mathrm{B}}\right]=$ Strong ion difference.

Figure 1 shows the overall $\Delta^{9}$-desaturase index and individual $\Delta^{9}$-desaturase indices for the 5 fatty acid pairs that represent product and substrate for $\Delta^{9}$-desaturase. There was a linear $(P<0.05$ and 0.13 , respectively) decline in the ratio of cis-9 16:1 and cis-9 18:1 $\Delta^{9}$-desaturase indices and a curvilinear $(P<0.05$ and 0.15 , respectively) decline in the ratio of cis-9 $14: 1$ and cis-9 10:1 $\Delta^{9}$-desaturase indices as DCAD increased; the overall $\Delta^{9}$-desaturase index showed a linear $(P<$ 0.05) decline as DCAD increased.

Milk pH was not affected by DCAD (Table 8), and there was no apparent effect of DCAD on the different fractions of milk protein measured. However, Ig tended $(P=0.11)$ toward a linear increase as DCAD declined, and lactoferrin concentration responded quadratically $(P=0.06)$ to changes in DCAD.

\section{DISCUSSION}

In much of the previous DCAD research with lactating cows, DCAD has been calculated using only $\mathrm{Na}$, $\mathrm{K}$, and $\mathrm{Cl}$ (Sanchez et al., 1994). In comparison, the equation most popularly used in the transition cow also includes $\mathrm{S}$, because of its acidifying properties (Tucker et al., 1992), and effect on Ca homeostasis (Roche et al., 2002). The original equation used by Sanchez et al. (1994) may be sufficient in systems where TMR is fed, because in trials where a benefit was reported, the advantage came from increasing the DCAD (West et al., 1991; 1992). Therefore, acidogenic materials are not as important in the equation as alkalinogenic ions. However, diets containing pasture have not been extensively investigated. In these diets, $\mathrm{K}$ concentration and DCAD often surpass (Roche et al., 2000) the values regarded as optimum by Sanchez et al. (1994), and in such a situation, S may be important. For this reason, the equation used to calculate $\mathrm{DCAD}$ in the research trial reported here was that of Tucker et al. (1992):

$$
\mathrm{DCAD}, \mathrm{mEq} / 100 \mathrm{~g} \text { of } \mathrm{DM}=(\mathrm{Na}+\mathrm{K})-(\mathrm{Cl}+\mathrm{S}) \text {. }
$$

Most measurements of acid-base status in this experiment showed a positive linear relationship with DCAD; that is, as DCAD increased, the systemic $\mathrm{pH}$ increased, base excess increased, and $\mathrm{HCO}_{3}{ }^{-}$increased. These results support the conclusions of Stewart (1981; 1983), that the concentrations of metabolically strong anions and cation determine the $\mathrm{pH}$ of fluids. These results 

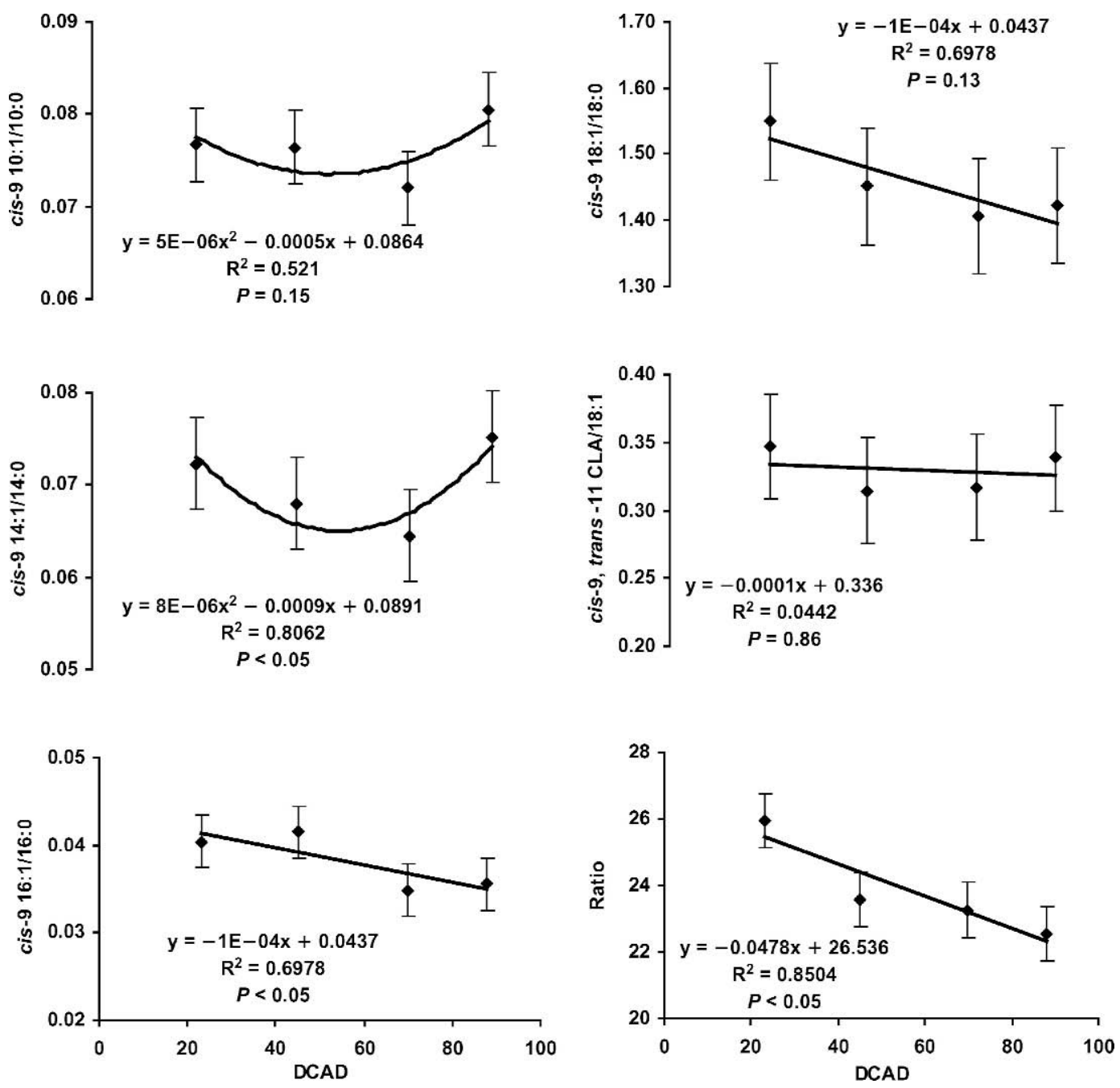

Figure 1. $\Delta^{9}$-Desaturase index for individual milk fatty acids that represent product and substrate for $\Delta^{9}$-desaturase and overall $\Delta^{9}$ desaturase index from dairy cows in early lactation offered fresh pasture and orally supplemented with mineral compounds containing either $\mathrm{Na}, \mathrm{Cl}, \mathrm{Ca}$, or $\mathrm{Mg}$, or a mixture of these minerals, to alter the dietary cation-anion difference (DCAD; mEq/100 g of DM). Values represent wk 5 of the treatment period.

are similar to those previously reported for cows fed pasture (Roche et al., 2003a), and cows fed TMR (Tucker et al., 1988; West et al., 1991). Although blood pH was marginally reduced with decreasing $\mathrm{DCAD},\left[\mathrm{SID}_{\mathrm{B}}\right]$ was not affected, highlighting the ability of the body to renally excrete ions that are surplus to requirements to maintain normal pH (Roche et al., 2003a). In support of this renal function, $\left[\mathrm{SID}_{\mathrm{U}}\right]$ declined linearly with declining DCAD, and the amount of $\mathrm{Na}$ and $\mathrm{Cl}$ in urine increased and decreased linearly as their concentrations in the diets increased and decreased, respectively. Urine $\mathrm{pH}$ cannot drop indefinitely, and the mammalian body has a threshold limit of approximately 4.5 (McGilvery, 1970; Houpt, 1993). A linear reduction in $\left[\mathrm{SID}_{\mathrm{U}}\right]$ with decreasing DCAD while $\mathrm{pH}$ declined curvilinearly illustrates the capacity of urine to resist changes in $\mathrm{pH}$.
The increase in serum $\mathrm{Na}$ and the decrease in serum $\mathrm{Cl}$ as DCAD increased were anticipated because of the increased dietary concentrations of these minerals as DCAD increased and decreased, respectively, and because of the high coefficient of absorption of these minerals (NRC, 2001). The increase in urinary Ca and blood ionized $\mathrm{Ca}$ as DCAD declined suggests that Ca homeostasis was altered in favor of increased intestinal absorption (Schonewille et al., 1994; Roche et al., 2003b, c) and possibly increased bone resorption (Block, 1984; Goff et al., 1991). However, because of the increased renal excretion of $\mathrm{Ca}$, no effect of DCAD on serum $\mathrm{Ca}$ concentration was evident, which is consistent with previous studies of lactating cows (Tucker and Hogue, 1990; West et al., 1991, 1992; Roche et al., 2003a). The nonsignificant curvilinear nature of the rise in urine 
Table 5. Urine $\mathrm{pH}$, strong ion difference of urine ( $\left[\mathrm{SID}_{\mathrm{U}}\right]$ ) and urine mineral to creatinine ratio of dairy cows in early lactation offered fresh pasture and orally supplemented with mineral compounds containing either $\mathrm{Na}, \mathrm{Cl}, \mathrm{Ca}$, or $\mathrm{Mg}$, or a mixture of these minerals, to alter the dietary cation-anion difference (DCAD).

\begin{tabular}{|c|c|c|c|c|c|c|c|c|}
\hline \multirow[b]{2}{*}{ Variable $^{1}$} & \multicolumn{4}{|c|}{ DCAD (mEq/100 g of DM) } & \multirow[b]{2}{*}{ SED } & \multicolumn{3}{|c|}{$P$} \\
\hline & 23 & 45 & 70 & 88 & & DCAD & Linear & Quadratic \\
\hline Urine pH & 7.93 & 8.25 & 8.30 & 8.36 & 0.077 & $<0.0001$ & $<0.0001$ & 0.02 \\
\hline $\begin{array}{l}{\left[\mathrm{SID}_{\mathrm{U}}\right]} \\
\text { Minerals }\end{array}$ & $-15,995$ & -9838 & -8461 & -5337 & 1515.4 & $<0.001$ & $<0.001$ & 0.17 \\
\hline $\mathrm{Ca} /$ Creat & 2.60 & 1.38 & 0.88 & 0.58 & 0.387 & $<0.0001$ & $<0.0001$ & 0.09 \\
\hline $\mathrm{Mg} /$ Creat & 2.01 & 2.14 & 2.19 & 2.08 & 0.295 & 0.94 & 0.76 & 0.56 \\
\hline $\mathrm{Na} /$ Creat & 8.48 & 9.36 & 10.52 & 19.73 & 1.987 & $<0.0001$ & $<0.0001$ & $<0.01$ \\
\hline K/Creat & 108.2 & 101.9 & 104.6 & 109.3 & 8.05 & 0.81 & 0.77 & 0.35 \\
\hline Cl/Creat & 70.2 & 49.9 & 38.4 & 31.6 & 5.19 & $<0.0001$ & $<0.0001$ & 0.07 \\
\hline S/Creat & 5.77 & 5.43 & 6.10 & 6.01 & 0.465 & 0.52 & 0.35 & 0.72 \\
\hline P/Creat & 0.04 & 0.04 & 0.04 & 0.04 & 0.005 & 0.91 & 0.73 & 0.81 \\
\hline
\end{tabular}

$\mathrm{Ca}$ as DCAD declines supports the assertion by Roche et al. $(2000 ; 2003 \mathrm{~b})$ that there is a threshold DCAD above which there is little or no effect of DCAD on $\mathrm{Ca}$ homeostasis. The suggestion that this threshold is +15 to $+20 \mathrm{mEq} / 100 \mathrm{~g}$ of $\mathrm{DM}$ is probably too low, based on the results reported here. However, this threshold may still be appropriate for periparturient cows precalving, which do not have the same demand for Ca.

Roche et al. (2003a) reported a decline in DMI and a corresponding numerical decrease in milk yield as DCAD increased. However, because of the extent of the DCAD range covered in their study $(+21$ to $+127 \mathrm{mEq} /$

Table 6. Mean daily DMI, milk yield, milk component yield, milk composition, solid fat content at $10^{\circ} \mathrm{C}$ $\left(\mathrm{SFC}_{10}\right), \log _{10} \mathrm{SCC}$, and milk mineral concentration of dairy cows in early lactation offered fresh pasture and orally supplemented with mineral compounds containing either $\mathrm{Na}, \mathrm{Cl}, \mathrm{Ca}$, or $\mathrm{Mg}$, or a mixture of these minerals, to alter the dietary cation-anion difference (DCAD).

\begin{tabular}{|c|c|c|c|c|c|c|c|c|}
\hline \multirow[b]{2}{*}{ Variable $^{1}$} & \multicolumn{4}{|c|}{ DCAD $(\mathrm{mEq} / 100 \mathrm{~g}$ of $\mathrm{DM})$} & \multirow[b]{2}{*}{ SED } & \multicolumn{3}{|c|}{$P$} \\
\hline & 23 & 45 & 70 & 88 & & DCAD & Linear & Quadratic \\
\hline Milk yield, $\mathrm{kg} / \mathrm{d}$ & 24.8 & 26.1 & 26.6 & 26.3 & 1.26 & 0.50 & 0.19 & 0.38 \\
\hline Fat, $\%$ & 3.96 & 4.06 & 4.22 & 4.17 & 0.123 & 0.19 & 0.04 & 0.44 \\
\hline Fat yield, $\mathrm{kg} / \mathrm{d}$ & 1.00 & 1.03 & 1.09 & 1.10 & 0.056 & 0.23 & 0.04 & 0.75 \\
\hline $\mathrm{CP}, \%$ & 3.43 & 3.44 & 3.40 & 3.39 & 0.048 & 0.69 & 0.29 & 0.66 \\
\hline CP yield, kg/d & 0.87 & 0.89 & 0.89 & 0.89 & 0.044 & 0.95 & 0.63 & 0.72 \\
\hline Total protein, \% & 3.18 & 3.18 & 3.15 & 3.14 & 0.047 & 0.79 & 0.34 & 0.81 \\
\hline Total protein yield, kg/d & 0.80 & 0.81 & 0.83 & 0.83 & 0.035 & 0.75 & 0.28 & 0.73 \\
\hline Lactose, \% & 4.90 & 4.88 & 4.92 & 4.92 & 0.037 & 0.78 & 0.52 & 0.69 \\
\hline Lactose yield, $\mathrm{kg} / \mathrm{d}$ & 1.25 & 1.27 & 1.28 & 1.29 & 0.066 & 0.94 & 0.52 & 0.84 \\
\hline Casein, \% & 2.64 & 2.61 & 2.59 & 2.60 & 0.037 & 0.65 & 0.23 & 0.59 \\
\hline Casein yield, $\mathrm{kg} / \mathrm{d}$ & 0.66 & 0.67 & 0.68 & 0.69 & 0.029 & 0.78 & 0.29 & 0.93 \\
\hline $\mathrm{SFC}_{10}$ & 52.7 & 54.2 & 54.6 & 56.9 & 1.15 & 0.01 & $<0.001$ & 0.66 \\
\hline $\log _{10} \mathrm{SCC}$ & 1.88 & 1.55 & 1.62 & 1.65 & 0.194 & 0.37 & 0.31 & 0.18 \\
\hline DMI, kg/d & 15.9 & 16.7 & 17.9 & 17.4 & 1.39 & 0.56 & 0.22 & 0.50 \\
\hline DMI, \% BW & 3.34 & 3.40 & 3.67 & 3.49 & 0.22 & 0.51 & 0.33 & 0.44 \\
\hline BW change, $\mathrm{kg} / \mathrm{d}$ & 0.28 & 0.20 & 0.27 & 0.50 & 0.216 & 0.54 & 0.26 & 0.31 \\
\hline BCS change & -0.11 & -0.19 & 0.00 & -0.06 & 0.096 & 0.26 & 0.27 & 0.93 \\
\hline \multicolumn{9}{|l|}{ Milk minerals, mg/100 g } \\
\hline $\mathrm{Na}$ & 311 & 321 & 308 & 314 & 11.2 & 0.72 & 0.93 & 0.82 \\
\hline $\mathrm{K}$ & 1611 & 1647 & 1612 & 1648 & 29.4 & 0.41 & 0.42 & 0.95 \\
\hline $\mathrm{Cl}$ & 859 & 827 & 826 & 861 & 36.5 & 0.64 & 0.92 & 0.19 \\
\hline $\mathrm{S}$ & 326 & 328 & 321 & 330 & 6.3 & 0.54 & 0.78 & 0.54 \\
\hline $\mathrm{Ca}$ & 1217 & 1249 & 1212 & 1256 & 28.3 & 0.31 & 0.36 & 0.82 \\
\hline $\mathrm{Mg}$ & 102 & 107 & 105 & 103 & 3.1 & 0.55 & 0.81 & 0.17 \\
\hline $\mathrm{P}$ & 1026 & 1030 & 1024 & 1028 & 21.0 & 0.99 & 0.97 & 0.99 \\
\hline $\mathrm{Fe}$ & 0.13 & 0.17 & 0.31 & 0.15 & 0.108 & 0.38 & 0.67 & 0.22 \\
\hline $\mathrm{Zn}$ & 3.82 & 3.91 & 3.65 & 3.83 & 0.168 & 0.51 & 0.67 & 0.74 \\
\hline $\mathrm{Cu}$ & 0.04 & 0.04 & 0.05 & 0.05 & 0.007 & 0.57 & 0.18 & 0.55 \\
\hline I & 0.06 & 0.07 & 0.07 & 0.07 & 0.005 & 0.43 & 0.12 & 0.93 \\
\hline $\mathrm{Se}$ & 0.01 & 0.02 & 0.01 & 0.01 & 0.004 & 0.48 & 0.64 & 0.34 \\
\hline
\end{tabular}


Table 7. Milk fatty acid profile ${ }^{1}$ of dairy cows in early lactation offered fresh pasture and orally supplemented with mineral compounds containing either $\mathrm{Na}, \mathrm{Cl}, \mathrm{Ca}$, or $\mathrm{Mg}$, or a mixture of these minerals, to alter the dietary cation-anion difference (DCAD).

\begin{tabular}{|c|c|c|c|c|c|c|c|c|}
\hline \multirow[b]{2}{*}{ Fatty acid } & \multicolumn{4}{|c|}{$\mathrm{DCAD}(\mathrm{mEq} / 100 \mathrm{~g}$ of $\mathrm{DM})$} & \multirow[b]{2}{*}{ SED } & \multicolumn{3}{|c|}{$P$} \\
\hline & 23 & 45 & 70 & 88 & & DCAD & Linear & Quadratic \\
\hline \multicolumn{9}{|l|}{ Fatty acid, \% } \\
\hline $4: 0$ to $15: 1$ & 30.13 & 32.52 & 31.41 & 30.79 & 1.112 & 0.20 & 0.88 & 0.06 \\
\hline $16: 0$ to $16: 1$ & 27.49 & 30.01 & 29.26 & 31.02 & 0.877 & $<0.01$ & $<0.01$ & 0.57 \\
\hline $17: 0$ to $20: 0$ & 42.54 & 37.56 & 39.26 & 38.05 & 1.695 & 0.03 & 0.05 & 0.12 \\
\hline $18: 0$ & 9.92 & 8.96 & 9.10 & 8.50 & 0.609 & 0.17 & 0.03 & 0.67 \\
\hline Trans-10 18:1 & 0.22 & 0.20 & 0.20 & 0.24 & 0.048 & 0.86 & 0.66 & 0.46 \\
\hline Trans-11 18: $1^{2}$ & 5.18 & 4.09 & 5.42 & 5.82 & 0.671 & 0.09 & 0.14 & 0.14 \\
\hline Trans-12 18:1 & 0.33 & 0.33 & 0.30 & 0.27 & 0.021 & 0.05 & $<0.01$ & 0.31 \\
\hline Cis-9 18:1 & 15.57 & 12.97 & 12.47 & 11.97 & 1.186 & 0.03 & $<0.01$ & 0.21 \\
\hline CLA $^{3}$ & 1.74 & 1.40 & 1.69 & 1.93 & 0.261 & 0.28 & 0.32 & 0.13 \\
\hline $18: 2^{4}$ & 0.90 & 0.77 & 0.79 & 0.73 & 0.073 & 0.18 & 0.05 & 0.49 \\
\hline $18: 3^{5}$ & 1.03 & 1.14 & 1.23 & 1.06 & 0.087 & 0.16 & 0.57 & 0.04 \\
\hline \multicolumn{9}{|l|}{ Fatty acid, mmol } \\
\hline $4: 0$ to $15: 1$ & 1879.7 & 2129.1 & 2190.1 & 2234.6 & 154.11 & 0.13 & 0.03 & 0.34 \\
\hline $16: 0$ to $16: 1$ & 1071.8 & 1245.9 & 1302.1 & 1393.0 & 83.79 & $<0.01$ & $<0.001$ & 0.48 \\
\hline $17: 0$ to $20: 0$ & 1459.2 & 1393.1 & 1600.7 & 1525.6 & 100.68 & 0.24 & 0.22 & 0.97 \\
\hline $18: 0$ & 337.9 & 328.0 & 365.3 & 341.5 & 30.64 & 0.68 & 0.63 & 0.75 \\
\hline Trans-10 18:1 & 7.1 & 7.4 & 8.2 & 9.6 & 1.63 & 0.45 & 0.10 & 0.64 \\
\hline Trans-11 18:12 & 173.8 & 156.1 & 217.5 & 236.0 & 26.82 & 0.02 & $<0.01$ & 0.37 \\
\hline Trans-12 18:1 & 11.1 & 11.8 & 12.0 & 11.1 & 0.85 & 0.61 & 0.99 & 0.18 \\
\hline Cis-9 18:1 & 536.8 & 476.1 & 510.1 & 484.9 & 54.67 & 0.69 & 0.47 & 0.64 \\
\hline $\mathrm{CLA}^{3}$ & 59.3 & 52.3 & 68.1 & 79.9 & 9.78 & 0.05 & 0.02 & 0.18 \\
\hline $18: 2^{4}$ & 31.8 & 28.5 & 32.0 & 29.6 & 3.46 & 0.71 & 0.84 & 0.80 \\
\hline $18: 3^{5}$ & 35.8 & 42.3 & 49.1 & 43.2 & 2.75 & $<0.001$ & $<0.01$ & $<0.01$ \\
\hline
\end{tabular}

${ }^{1}$ Measurements are from wk 5 of treatment period.

${ }^{2}$ Vaccenic acid.

${ }^{3}$ Cis-9, trans-11 conjugated linoleic acid (CLA).

${ }^{4}$ Linoleic acid.

${ }^{5}$ Linolenic acid.

$100 \mathrm{~g}$ of DM), it was not possible to determine the optimum DCAD for DMI and milk production. It was assumed that DMI and milk yield declined above +21 $\mathrm{mEq} / 100 \mathrm{~g}$ of DM, which was consistent with the optimal DCAD proposed by Sanchez et al. (1994). The DCAD range investigated in the experiment reported here was considerably smaller $(+23$ to $+88 \mathrm{mEq} / 100 \mathrm{~g}$ of $\mathrm{DM}$ ), potentially allowing the optimum DCAD for DMI and milk production to be identified. Although a numerical increase in DMI and milk production was observed in the current study, it was not statistically significant. However, this may have been a result of insufficient animal numbers, because the most likely reason for the increase in milk fat yield and, in particular, the increase in the yield of linolenic acid, VA, and cis-9, trans-11 CLA, is an increase in DMI. Kay et al. (2004) showed that greater than $90 \%$ of $c i s-9$, trans- 11 CLA in the milk of pasture cows was a result of mammary desaturation of VA, a product of the biohydrogenation of dietary linolenic acid. Therefore, considering that the yields of stearic and oleic acids were not affected by DCAD, the only possible reason for an increase in the yield of linolenic acid, VA, and cis-9, trans-11
CLA is an actual increase in DMI (Stockdale et al., 2001; D. Palmquist, personal communication, 2004). These findings suggest that the optimal DCAD for production in pasture-based systems may be higher than was previously suggested by Sanchez et al. (1994). Before this study, with the exception of Roche et al. (2003a), there was very little information on the effects of DCAD in excess of $+25 \mathrm{mEq} / 100 \mathrm{~g}$ of $\mathrm{DM}$ and no information on the effects of DCAD in pasture-based systems to validate the model presented by Sanchez et al. (1994).

Milk fat concentration and yield increased with increasing DCAD, supporting earlier research that also demonstrated a positive relationship between DCAD and milk fat concentration and yield (Escobosa et al., 1984; Schneider et al., 1986; Tucker et al., 1988, 1993; West et al., 1991). Similarly, Chiy and Phillips (2000) reported an increase in milk fat concentration and yield in cows grazing pasture with an elevated $\mathrm{Na}$ concentration. What has not been known from previous work was whether the additional milk fat was a result of increased uptake of preformed fatty acids from the circulatory system, possibly due to increased DMI, or be- 
Table 8. The $\mathrm{pH}$ of milk and the mean daily concentration ${ }^{1}$ of urea, total color, Ig, bovine serum albumin, lactoferrin, $\alpha, \beta, \kappa$, and $\gamma$ casein, $\alpha \mathrm{LA}$, and $\beta \mathrm{LG}$ in milk from dairy cows in early lactation offered fresh pasture and orally supplemented with mineral compounds containing either $\mathrm{Na}, \mathrm{Cl}, \mathrm{Ca}$, or $\mathrm{Mg}$, or a mixture of these minerals, to alter the dietary cation-anion difference (DCAD).

\begin{tabular}{|c|c|c|c|c|c|c|c|c|}
\hline \multirow[b]{2}{*}{ Variable $^{1}$} & \multicolumn{4}{|c|}{ DCAD $(\mathrm{mEq} / 100 \mathrm{~g}$ of $\mathrm{DM})$} & \multirow[b]{2}{*}{ SED } & \multicolumn{3}{|c|}{$P$} \\
\hline & 23 & 45 & 70 & 88 & & DCAD & Linear & Quadratic \\
\hline Milk pH & 6.660 & 6.643 & 6.654 & 6.652 & 0.017 & 0.78 & 0.83 & 0.50 \\
\hline Urea, $\mathrm{mmol} / \mathrm{L}$ & 6.171 & 6.886 & 7.031 & 6.918 & 0.529 & 0.33 & 0.15 & 0.22 \\
\hline Total color ${ }^{2}$ & 0.421 & 0.415 & 0.432 & 0.438 & 0.033 & 0.90 & 0.51 & 0.77 \\
\hline Ig, mg/L & 540 & 500 & 497 & 465 & 44.1 & 0.46 & 0.11 & 0.94 \\
\hline BSA, mg/L & 206.2 & 177.2 & 182.3 & 178.2 & 21.41 & 0.51 & 0.24 & 0.41 \\
\hline Lactoferrin, g/kg & 148.1 & 91.6 & 56.9 & 99.6 & 36.68 & 0.15 & 0.16 & 0.06 \\
\hline$\alpha$-Casein, $\mathrm{g} / \mathrm{kg}$ & 11.2 & 12.0 & 12.0 & 12.1 & 0.61 & 0.39 & 0.13 & 0.39 \\
\hline$\beta$-Casein, $\mathrm{g} / \mathrm{kg}$ & 10.4 & 10.3 & 10.4 & 9.7 & 0.56 & 0.53 & 0.23 & 0.46 \\
\hline$\kappa$-Casein, $\mathrm{g} / \mathrm{kg}$ & 3.5 & 3.5 & 3.2 & 3.3 & 0.21 & 0.47 & 0.16 & 0.70 \\
\hline$\gamma$-Casein, g/kg & 3.9 & 4.0 & 4.1 & 4.1 & 0.28 & 0.92 & 0.50 & 0.87 \\
\hline$\alpha$-Lactalbumin, $\mathrm{g} / \mathrm{kg}$ & 0.9 & 0.9 & 0.8 & 0.8 & 0.10 & 0.72 & 0.28 & 0.93 \\
\hline$\beta$-Lactoglobulin, $\mathrm{g} / \mathrm{kg}$ & 0.4 & 0.3 & 0.4 & 0.3 & 0.09 & 0.85 & 0.84 & 0.96 \\
\hline
\end{tabular}

${ }^{1}$ All measurements completed on skim milk except for total color.

${ }^{2}$ Total color measured as $\beta$-carotene equivalents.

cause of increased de novo synthesis of fatty acids within the mammary epithelial cells. De novo synthesis accounts for approximately $60 \%$ of bovine milk fatty acids; fatty acids with carbon chains 4:0 to 14:0 and approximately one-half of the 16:0 and $16: 1$ fatty acids in milk are almost exclusively derived from de novo fatty acid synthesis (Bauman and Davis, 1974).

On examination of milk fatty acid yields (Table 7), it is evident that an increasing DCAD raised the production of short (4:0 to 15:1) and medium (16:0 to $16: 1$ ) chain fatty acids, with the yield of palmitic acid (16:0) increasing by $30 \%$. These results indicate an elevation in de novo fatty acid production, although the increase in milk VA and linolenic acid yield also suggests an increased uptake of preformed fatty acids from the blood.

There are several possible reasons for the increase in de novo fatty acid synthesis. De novo milk fat synthesis occurs in the cytoplasm of the mammary epithelial cells and requires acetyl coenzyme-A and BHBA (Dils, 1983), both of which are primarily derived from ruminal fermentation. In the experiment reported here, as discussed earlier, there may have been an increase in DMI as DCAD increased. If this effect were real, the increase in DMI would be expected to result in greater VFA production in the rumen and provide more substrate for de novo fatty acid production.

Another possibility is a positive relationship between DCAD and rumen $\mathrm{pH}$, as was previously reported by Tucker et al. (1988). The mean daily $\mathrm{pH}$ of ruminal contents in cows grazing highly digestible pasture has been reported to be as low as 5.8 (Kolver and de Veth, 2002). If an increasing DCAD were to increase the $\mathrm{pH}$ of ruminal contents, the fermentation pattern would be expected to shift in favor of acetate and butyrate production (Kaufmann et al., 1980; Kolver and de Veth, 2002), resulting in increased substrate for de novo fatty acid synthesis. The linear increase in blood urea concentrations combined with the linear decline in liver vitamin $B_{12}$ concentrations also indicates that increasing DCAD had an effect on the metabolism of rumen microorganisms. The linear decrease in the milk fat concentration of trans-12 18:1 as DCAD increased, and the trend for a corresponding increase in VA suggests that isomerization of fatty acids during ruminal biohydrogenation may have been affected by DCAD, possibly through altering ruminal $\mathrm{pH}$.

Even though the most likely reason for the increase in milk fat production and the change in milk fatty acid profile appears to be an effect of DCAD on DMI or ruminal fermentation, an effect of treatment on mammary function cannot be ruled out. The overall $\Delta^{9}$-desaturase index declined linearly with increasing DCAD, suggesting a possible effect of DCAD on mammary gland $\Delta^{9}$-desaturase function. However, the inconsistent effects of DCAD on the individual $\Delta^{9}$-desaturase indices do not support this hypothesis and we maintain that the reason for the increased de novo synthesis of milk fatty acids was an increase in substrate because of either greater DMI or elevated rumen $\mathrm{pH}$.

In conclusion, blood $\mathrm{pH}$ and urine $\mathrm{pH}$ in lactating cows grazing pasture increased with increasing DCAD and de novo fatty acid synthesis was positively correlated with DCAD.

\section{ACKNOWLEDGMENTS}

The authors acknowledge the assistance of E. Kolver, L. Baumgard, and B. Wales, the technical expertise of 
P. Thorne, the statistical expertise of B. Dow, all the help afforded them by No. 5 dairy staff and the laboratory expertise of Alpha Scientific, Gribbles and Hills, Hamilton, New Zealand. This work was funded by New Zealand Dairy Farmers, through the Global Program research fund, and the Foundation for Research Science and Technology.

\section{REFERENCES}

Barbano, D. M., J. M. Lynch, and J. R. Fleming. 1991. Direct and indirect determination of true protein content of milk by Kjeldahl analysis: Collaborative study. J. AOAC 74:281-288.

Bauman, D. E., and C. L. Davis. 1974. Biosynthesis of milk fat. Pages 31-75 in Lactation: A Comprehensive Treatise, Vol. 2. B. L. Larson and V. R. Smith, ed. Academic Press, New York, NY.

Block, E. 1984. Manipulating dietary anions and cations for prepartum dairy cows to reduce incidence of milk fever. J. Dairy Sci. 67:2939-2948.

Chiy, P. C., and C. J. C. Phillips. 2000. Sodium fertilizer application to pasture. 10. A comparison of the responses of dairy cows with high and low milk yield potential. Grass Forage Sci. 55:343-350.

Dillon, P. 1993. The use of n-alkanes as markers to determine intake, botanical composition of available and consumed herbage in studies of digesta kinetics with dairy cows. Ph.D. Thesis, Natl. Univ. of Ireland, Dublin.

Dillon, P., and G. Stakelum. 1989. Herbage and dosed alkanes as a grass measurement technique for dairy cows. Irish J. Agric. Res. 28:104. (Abstr.)

Dils, R. R. 1983. Milk fat synthesis. Pages 141-157 in Biochemistry of Lactation. T. P. Mepham, ed. Elsevier Sci. Publ., Amsterdam, The Netherlands.

Escobosa, A., C. E. Coppock, L. D. Rowe, W. L. Jenkins, and C. E. Gates. 1984. Effects of dietary sodium bicarbonate and calcium chloride on physiological responses of lactating dairy cows in hot weather. J. Dairy Sci. 67:574-584.

Everitt, B. S. 1995. The analysis of repeated measures: A practical review with examples. Statistician 44:113-135.

Genstat V. 1997. Genstat 5, Release 4.1, Reference Manual. Oxford Univ. Press, Oxford, UK.

Goff, J. P., R. L. Horst, F. J. Mueller, J. K. Miller, G. A. Kiess, and H. H. Dowlen. 1991. Addition of chloride to a prepartal diet high in cations increases 1,25-dihydroxyvitamin D response to hypocalcemia preventing milk fever. J. Dairy Sci. 74:3863-3871.

Green, R., P. A. Newmark, A. M. Musso, and D. L. Mollin. 1974. Use of chick serum for measurement of serum B12 concentration by radioisotope dilution: Description of method and comparison with microbial assay results. Br. J. Haem. 27:507-526.

Holmes, C. W., and G. F. Wilson. 1987. Nutrition: Quantitative requirements of dairy cattle. Pages 107-130 in Chapter 13: Milk Production from Pasture. Butterworths Agric. Books, Wellington, New Zealand.

Houpt, T. R. 1993. Acid-base balance. Pages 604-615 in Dukes' Physiology of Domestic Animals. 11th ed. M. J. Swenson, ed. Cornell Univ. Press, Ithaca, NY.

International Dairy Federation. 1987. Milk: Determination of fat content - Röse-Gottlieb gravimetric method (reference method) in IDF Standard FIL-IDF. Vol. 1C. Brussels, Belgium.

Kaufmann, W., H. Hagemeister, and G. Dirksen. 1980. Adaptations to changes in dietary composition, level and frequency of feeding, Page 587 in Digestive Physiology and Metabolism in Ruminants. Y. Ruckebusch and P. Thivend, ed. AVI Publ. Co., Westport, CT.

Kay, J. K., T. R. Mackle, M. J. Auldist, N. A. Thomson, and D. E. Bauman. 2004. Endogenous synthesis of cis-9, trans-11 conjugated linoleic acid in dairy cows fed fresh pasture. J. Dairy Sci. 87:369-378.

Kennedy, J., P. Dillon, L. Delaby, P. Faverdin, G. Stakelum, and M. Rath. 2003. Effect of genetic merit and concentrate supplementa- tion on grass intake and milk production with Holstein-Friesian dairy cows. J. Dairy Sci. 86:610-621.

Kolver, E. S., and M. J. de Veth. 2002. Prediction of ruminal pH from pasture-based diets. J. Dairy Sci. 85:1255-1266.

MacGibbon, A. K. H. 1988. Modified method of fat extraction for solid fat content determination. N.Z. J. Dairy Sci. Technol. 23:399-403.

MacGibbon, A. K. H., and W. D. McLennan. 1987. Hardness of New Zealand patted butter: Seasonal and regional variations. N.Z. J. Dairy Sci. Technol. 22:143-156.

Mackle, T. R., A. M. Bryant, S. F. Petch, R. J. Hooper, and M. J. Auldist. 1999. Variation in the composition of milk protein from pasture-fed dairy cows in late lactation and the effect of grain and silage supplementation. N.Z. J. Agric. Res. 42:147-154.

McGilvery, R. W. 1970. Respiratory exchange and H+ balance. Pages 608-628 in Biochemistry, A Functional Approach. W. B. Saunders, Philadelphia, PA.

Manderson, G. A., M. J. Hardman, and L. K. Creamer. 1998. Effect of heat treatment on the conformation and aggregation of $\beta$-lactoglobulin A, B, and C. J. Agric. Food Sci. Chem. 46:5052-5061.

Mayes, R. W., C. S. Lamb, and P. M. Colgrove. 1986. The use of dosed and herbage n-alkanes as markers for the determination of herbage intake. J. Agric. Sci. (Camb.) 107:161-170.

Morton, J., and C. Roach. 2002. Potash - How does it affect production and cow health? Pages 19-23 in Proc. Westpac Trust Dairy Conf. Taranaki, New Zealand.

National Research Council. 1989. Pages 2-51 in Nutrient Requirements of Dairy Cattle. 6th rev. ed. Nat. Acad. Sci., Washington, DC.

National Research Council. 2001. Pages 106-131 in Nutrient Requirements of Dairy Cattle. 7th rev. ed. Natl. Acad. Sci., Washington, DC.

Norris, R., I. K. Gray, A. K. R. McDowell, and R. M. Dolby. 1971. The chemical composition and physical properties of fractions of milk fat obtained by a commercial fractionation process. J. Dairy Res. 38:179-191.

O'Donovan, M. 2000. The relationship between the performance of dairy cows and grassland management practise on intensive dairy farms in Ireland. Ph.D. Diss., Natl. Univ. of Ireland, Dublin.

Roche, J. R. 1999. Dietary Cation-Anion Difference for Pasture-fed Dairy Cows. Ph.D. Diss., University College, Dublin, Ireland.

Roche, J. R., D. E. Dalley, P. J. Moate, C. Grainger, M. Hannah, F. O'Mara, and M. Rath. 2000. Variations in the dietary cationanion difference and the acid-base balance of dairy cows on a pasture-based diet in southeastern Australia. Grass Forage Sci. $55: 26-36$.

Roche, J. R., D. E. Dalley, P. J. Moate, C. Grainger, M. Rath, and F. O'Mara. 2003a. Dietary cation-anion difference and the health and production of pasture-fed dairy cows. 1. Dairy cows in early lactation. J. Dairy Sci. 86:970-978.

Roche, J. R., D. E. Dalley, P. J. Moate, C. Grainger, M. Rath, and F. O'Mara. 2003b. Dietary cation-anion difference and the health and production of pasture-fed dairy cows. 2. Non-lactating periparturient cows. J. Dairy Sci. 86:979-987.

Roche, J. R., D. E. Dalley, P. J. Moate, C. Grainger, M. Rath, and F. O'Mara. 2003c. A low dietary cation-anion difference precalving and calcium supplementation postcalving increase plasma calcium but not milk production in a pasture-based system. J. Dairy Sci. 86:2658-2666.

Roche, J. R., J. Morton, and E. S. Kolver. 2002. Sulfur and chlorine play a non-acid base role in periparturient calcium homeostasis. J. Dairy Sci. 85:3444-3453.

Sanchez, W. K., D. K. Beede, and M. A. Delorenzo. 1994. Macromineral element relationships and lactational performance: Empirical models from a large data set. J. Dairy Sci. 77:3096-3110.

Schneider, P. L., D. K. Beede, and C. J. Wilcox. 1986. Responses of lactating cows to dietary sodium source and quantity and potassium quantity during heat stress. J. Dairy Sci. 69:99-110.

Schonewille, J. T., A. T. Van't Klooster, A. Dirkswager, and A. Bayen. 1994. Stimulatory effect of an anion (chloride)-rich ration on apparent calcium absorption in dairy cows. Livest. Prod. Sci. 40:233-240. 
Stewart, P. A. 1981. How to understand acid-base-A quantitative acid-base primer for biology and medicine. Edward Arnold, London, UK.

Stewart, P. A. 1983. Modern quantitative acid-base chemistry. Can. J Physiol. Pharm. 61:1444-1461.

Stockdale, C. R., G. P. Walker, W. J. Wales, D. E. Dalley, A. Birkett, Z. Shen, and P. T. Doyle. 2001. Effect of pasture intake on CLA in the milkfat of grazing dairy cows. Aust. J. Dairy. Technol. 56:161. (Abstr.)

Tucker, W. B., G. A. Harrison, and R. W. Hemken. 1988. Influence of dietary cation-anion balance on milk, blood, urine and rumen fluid in lactating dairy cattle. J. Dairy Sci. 71:346-354.

Tucker, W. B., and J. F. Hogue. 1990. Influence of sodium chloride or potassium chloride on systemic acid-base status, milk yield, and mineral metabolism in lactating cows. J. Dairy Sci. 73:3485-3493.
Tucker, W. B., J. F. Hogue, M. Aslam, M. Lema, P. Le Ruyet, I. S. Shin, M. T. Van Koevering, R. K. Vernon, and G. D. Adams. 1993. Controlled ruminal infusion of sodium bicarbonate. 3 . Influence of infusion dose on systemic acid-base status, minerals and ruminal milieu. J. Dairy Sci. 76:2222-2234.

Tucker, W. B., J. F. Hogue, D. F. Waterman, T. S. Swenson, Z. Xin, R. W. Hemken, J. A. Jackson, G. D. Adams, and L. J. Spicer. 1992. Sulfur should be included when calculating the dietary cation-anion balance of diets for lactating dairy cows. Pages 141150 in Anim. Sci. Res. Rep., Oklahoma Res. Stat., Oklahoma City, OK.

West, J. W., K. D. Haydon, B. G. Mullinix, and T. G. Sandifer. 1992. Dietary cation-anion balance and cation source effects on production and acid-base status of heat stressed cows. J. Dairy Sci. 75:2776-2786.

West, J. W., B. G. Mullinix, and T. G. Sandifer. 1991. Changing dietary electrolyte balance for dairy cows in cool and hot environments. J. Dairy Sci. 74:1662-1674. 